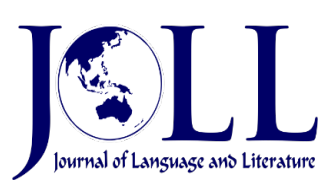

Vol. 21 No. 2, October 2021, pp. 307-317

DOI: 10.24071/joll.v21i2.3132

Available at https://e-journal.usd.ac.id/index.php/JOLL/index

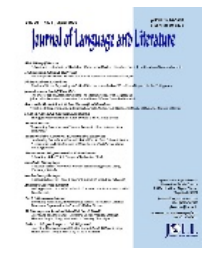

This work is licensed under a Creative Commons Attribution-ShareAlike 4.0 International License.

\title{
Facing Anxiety through Ego Defense Mechanisms on The Walking Dead: Michonne Movie Game
}

\author{
1Fery Setiawan, ${ }^{2}$ I Gusti Agung Sri Rwa Jayantini, ${ }^{3}$ Ida Bagus Gde Nova Winarta, \\ ${ }^{4}$ Ni Komang Arie Suwastini \\ fery.fbaunmas@gmail.com, *agung_srijayantini@unmas.ac.id,idabagusnova@unmas.ac.id, \\ arie.suwastini@undiksha.ac.id \\ 1,2,3 Universitas Mahasaraswati Denpasar, ${ }^{4}$ Universitas Pendidikan Ganesha, INDONESIA
}

\begin{abstract}
With the advancement of technology, a newly adopted form of literary work was found, known as a movie game. It is one of the game genres that resembles real movies that provide choices to the players who can actively determine the story, ending, and characters' action. In literary work, a character is one of the intrinsic elements that can be interestingly analyzed from the psychological perspective, including Ego Defense Mechanisms. This study focuses on how the protagonist in a movie game entitled The Walking Dead: Michonne faced her anxiety through her ego defense mechanisms. It aims to identify the types of ego defense mechanisms and how they can help the protagonist cope with her anxiety. The discussion was based on psychoanalysis theory, namely Ego Defense Mechanisms proposed by Sigmund Freud. This study elaborated the description of the protagonist's actions when she faced anxiety through a qualitative method. The analysis revealed that the protagonist adopted the four types of Ego Defense Mechanisms: repression, sublimation, rationalization, and aggression. It was found that aggression was the most frequently adopted mechanism, followed by sublimation, rationalization, and the least was repression. This finding indicated that the protagonist chose aggression to release resentment or dissatisfaction, especially when facing objects or other characters that create anxiety or frustration. It implies that the persistence of aggression, sublimation, rationalization, and repression could reflect the presence of continual threats in the environment from which people should survive.
\end{abstract} information

Received:

21 February

2021

Revised: 3 May 2021

Accepted: 10 May 2021

Keywords: movie game; ego defense mechanisms; anxiety; 


\section{Introduction}

As our cultures and communities evolved, there has been a massive evolution of the styles of literature. It is shaped by various thoughts, behaviors, attitudes, and languages expressed in everyday or social life (Rexroth, 2019). One of the well-known literary works is a film or movie. Visually, it delivers the message of literature to the viewers. With the development of technologies and as time progresses, there has been a massive evolution in literature in which the elements were adapted into video games. A video game can be played on various devices, such as a personal computer (PC), gaming consoles, and smartphones (Novrialdy, 2019). The development of technology, especially video games, could bring both negative and positive impacts. The negative impacts of playing video games are time-wasting, health problems, and addiction (Hasan, 2019; Setiawan, 2018). However, there are also some positive impacts when someone plays video games, such as reducing stress, forming sportsmanship and teamwork, and improving reasoning and logic skills (Chandiwati et al., 2016; Manggena, Putra, \& Elingsetyo Sanubari, 2017; Suwastini et al. 2020).

Character is one of the intrinsic elements in literature that can be adapted into video games. A psychological approach may also be applied to review the existence of character in video games. The significance of psychoanalysis in any literary works is to understand how it represents the psychological experience of human beings and the understanding of the characters' behavior (Pangestu \& Sunardi, 2016). Moreover, psychoanalysis theory can be a psychological interpretation to understand the meaning behind the character's action (Hossain, 2017). It includes learning Ego Defense Mechanisms when facing a threatening situation. There are many video game genres, and one of them is a movie game. It is a type of video game or genre that offers the player multiple choices as the game progresses. It has a branching plot and the choices provided within a movie game that will tailor the storyline and the main character's actions (Henman, 2019).
Ego Defense Mechanisms are known as the part of personality development within a person (Minderop, 2010). Ego Defense Mechanisms are helpful to reduce or prevent negative emotions, specifically anxiety, from arising within someone when he or she experiences an uncomfortable situation (Khoirunisa \& Rahayu, 2020; Martono, Rosa, \& Azmin, 2015; Santoso, 2017; Syahran, 2019). It always unconsciously arises to perform specific actions to protect ones from being harmed mentally (Nurtjahyo, 2016; Purwaningrum \& Haryati S., 2016). In a survival situation, anxiety will arise because someone is forced to do something to stay alive. It is the feeling when someone feels overwhelmed by the pressuring situation, and it causes fear and worries (Ulfa \& Wulandari, 2019; Warkey, Sili, \& Asanti, 2020). Many actions or survival-themed literary works such as novels, short stories, movies, and games show the struggle and anxiety felt by the protagonist (Al Khoiriyah, 2019; Musoffa, Multazim, Husna, Hudayah, \& Dramestika, 2019; Pratama \& Aji, 2017).

They do not reflect on one's personality in general, but they affect the development of personality. Freud (1896) categorizes Ego Defense Mechanisms into nine types: repression, sublimation, projection, displacement, rationalization, reaction formation, regression, aggression, and fantasy (Minderop, 2010).

1. Repression is an internal process created by the ego to prevent unpleasant or threatening feelings from entering our unconscious mind. For example, an older sister represses her hatred towards her younger sister (Semiun, 2006, p. 97).

2. Sublimation is a form of diversion. Its objective is to replace the feeling of fear or anxiety with socially beneficial activities. For example, a person who has a strong sexual desire then turns this uncomfortable feeling into brilliant ideas, such as creating a painting of a nude model (Minderop, 2010, p. 30).

3. Projection is placing one's uncomfortable or unpleasant feelings on another person or object. For example, when we have to be rude to someone, we know that it is wrong and unacceptable, 
but the attitude is carried out because the person deserves it. This kind of attitude is done to make us look better (Minderop, 2010, p. 34).

4. Displacement is a means of displacing a feeling of hatred towards someone or something else. For example, aggressive impulses may be displaced, as in scapegoating, upon people or objects who/which are not the source of the frustration but safer to attack (Minderop, 2010, p. 35).

5. Rationalization is to give a person reasonable motives for his or her actions. For example, a student makes an excuse that he deserves to go to a party because he constantly studies hard all this time (Minderop, 2010, p. 36).

6. Reaction Formation is when someone acts the opposite way of what they experience or feel. For example, a mother's excessive manifestations of concern for her child may mask an actual hostility towards the child: extreme politeness toward a person may mean concealed disdain; bravado may mean hidden fear (Minderop, 2010, p. 37).

7. Regression is when someone acts in an uncontrollable behavior or acts like a child. For example, smoking, excessive eating, destroying things, driving carelessly, getting into a fight, killing each other, and many childish acts (Hall, 2019, p. 173).

8. Aggression is the act of releasing resentment or dissatisfaction shown specifically to another object or someone that creates anxiety or frustration. For example, when someone is frustrated over something, he/she will find someone as a scapegoat to vent his/her anger (Minderop, 2010, p. 39).

9. Fantasy is the act of fantasizing about something to reduce anxiety and also to find a solution. For example, soldiers often put the images of pin-up girls within their barracks, which symbolizes that their life fantasy still goes on when their sexual life is interrupted (Minderop, 2010, p. 39).

The Walking Dead: Michonne is a threeepisode movie game from Telltale Games, published in 2016. The movie game was based on a comic with an identical title, The Walking Dead. Critics praised the atmosphere in this movie game along with the action sequences and the character development of Michonne, the protagonist. The trailer of this movie game can be seen through the following link https://youtu.be/fBQJyoal7AI, and the gameplay can be seen through the link https://youtu.be/pmilFwFX2Ag.

This study focuses on how the protagonist, Michonne, handles her anxiety through the Ego Defense Mechanisms in a movie game entitled The Walking Dead : Michonne, which tells and shows the protagonist's journey during the zombie outbreak to the viewers or players. Michonne was chosen as the subject of this study because her struggle to survive during the zombie outbreak was predominantly shown in the movie game. Moreover, she lost her daughters during the zombie outbreak and desperately looking for them. Michonne herself was not sure whether her daughters were still alive or not. She had to deal not only with zombies but also with other evil human beings. To survive during the life-threatening situation, she has to deal with her anxiety during the zombie outbreak. Michonne is not an experienced fighter. She was just an ordinary mother and a businesswoman before the world suddenly turns to vain, and in order to survive, she needs to learn everything the hard way, which tortures her sanity. Therefore, Ego Defense Mechanisms were worth analyzing because grasping the idea behind Ego Defense Mechanisms helps people understand how and why they react as it is towards the anxiety felt during a specific situation, especially when facing a threatening situation. Therefore, this study is expected to be helpful as a future reference for other researchers and give an overview of how Ego Defense Mechanisms influence someone's actions and reactions when he or she feels threatened to cope with the anxiety in order to live a balanced life.

Previously, five studies had analyzed Ego Defense Mechanisms focusing on the main characters of literary works. The studies were respectively conducted by Martono et al. (2015), Nurtjahyo (2016), Santoso (2017), Ulfa and Wulandari (2019), as well as 
Suwastini et al. (2020). These studies found some types of Ego Defense Mechanisms from the main characters of the literary works to help them cope with their anxiety. Repression was found in all of these previous studies. Concerning the previous findings, this study is projected to connect the influence of Ego Defense Mechanisms on a person's actions and reactions when experiencing stress by elaborating the Ego Defense Mechanisms theory by Sigmund Freud with other theories related to a person's psychological condition.

Although the present study and previous studies analyzed a similar topic, the difference can be noted from the data source. The previous studies used novels, while the present study used a movie game as the data source. The movie game was chosen as the data source because it allows the player to be an active participant. Therefore, the player could actively control and determine the story, ending, and character in the movie game, unlike movies that only present a linear story. Most of the time, people consider games as entertainment to reduce boredom and fill their spare time, while in reality, a game, specifically a movie game, can also be comprehensively analyzed to give a new perspective and knowledge for researchers.

\section{Methodology}

This study applied a descriptive qualitative method. Several steps were done in this study. Those steps were downloading and playing The Walking Dead: Michonne movie game, recording the gameplay, editing the gameplay to make it like a movie, rewatching the gameplay, and the last step was observing and taking notes to record the critical information related to the Ego Defense Mechanisms. The research design and the explanation can be seen in figure 1 .

\section{Figure 1 Research Design}

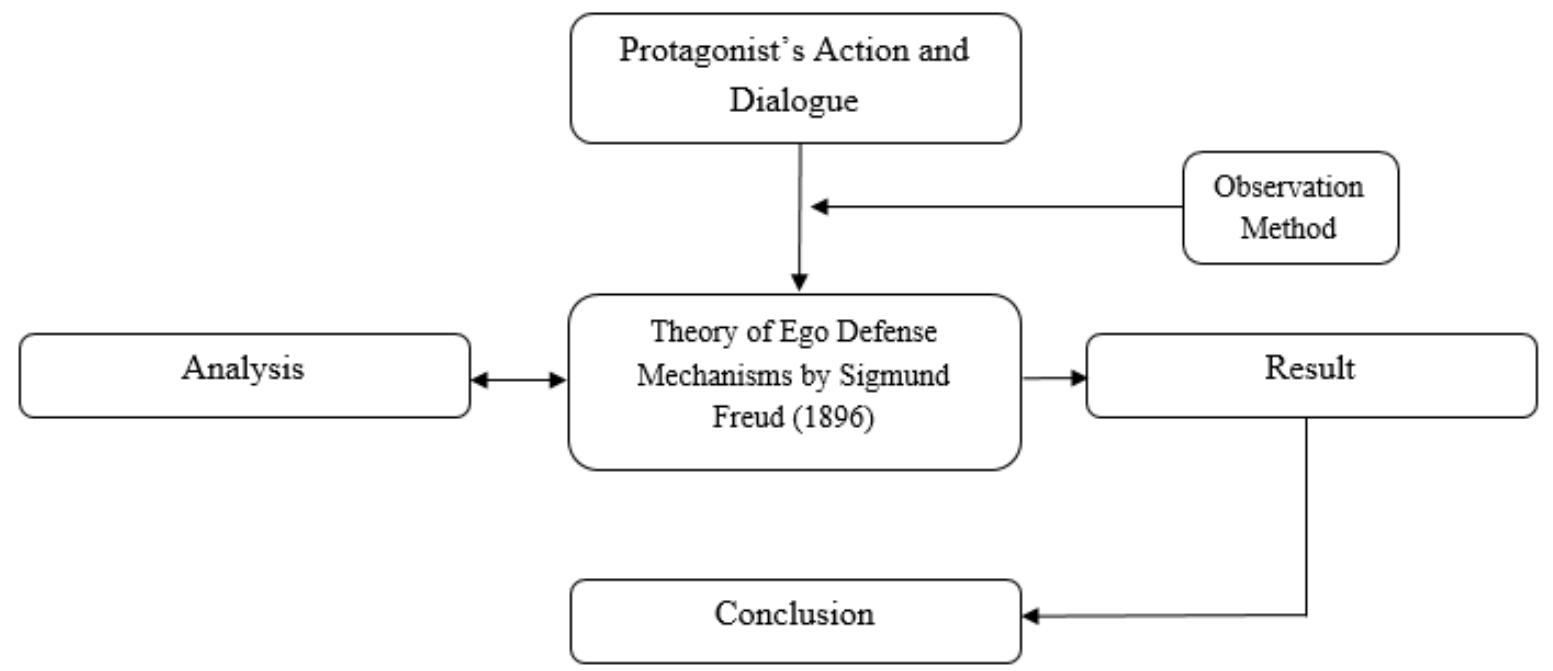

The data presented in this study were taken from The Walking Dead : Michonne movie game by Telltale Games, which was downloaded from the following link https://store.steampowered.com/app/42957 $\underline{0}$ /The Walking Dead Michonne A Telltale Miniseries/. The Ego Defense Mechanisms of the protagonist were analyzed in this study. This study used an observation method to collect the data within the movie game. In collecting the data, some steps were done such as downloading the movie game from the Steam website, playing the movie game, which consists of three episodes, recording the gameplay while playing the movie game, editing the recorded gameplay to make it resembles a real movie, rewatching the final result of the edited gameplay. The last step was observing and taking notes while rewatching the gameplay to write down the vital information on the Ego Defense 
Mechanisms of the protagonist from the movie game.

In this study, the protagonist's action and dialogue were thoroughly observed. The data were analyzed by applying the qualitative method to identify how the protagonist dealt with her anxiety through Ego Defense Mechanisms. The data were collected from the protagonist's actions and dialogue by observing them. The analysis then analyzed the protagonist's actions and dialogue and matched it with the theory of Ego Defense Mechanisms by Sigmund Freud. During the process of analysis, the descriptive qualitative method was applied. The presentation of analysis was supported by providing the pictures taken from the movie game to make the description clearer and more evident.

\section{Results and Discussion}

In The Walking Dead: Michonne movie game, four types of Ego Defense Mechanisms were adopted by the protagonist, as shown in the table below.

Table 1. Protagonist's Ego Defense Mechanisms

\begin{tabular}{|c|c|c|}
\hline Type & Occurrence & Percentage \\
\hline Repression & 7 & $19 \%$ \\
\hline Sublimation & 10 & $27 \%$ \\
\hline Rationalization & 8 & $22 \%$ \\
\hline Aggression & 12 & $32 \%$ \\
\hline \multicolumn{2}{|c|}{ Total } & $100 \%$ \\
\hline
\end{tabular}

Based on the findings in the table, there were four types of Ego Defense Mechanisms found from the protagonist in The Walking Dead: Michonne movie game, namely repression, sublimation, rationalization, and aggression. Aggression mainly was applied with 12 times of occurrence (32\%), followed by sublimation, i.e., ten times $(27 \%)$, rationalization, i.e., eight times (22\%), and the least was repression which occurred seven times (19\%). These defense mechanisms were used to help the protagonist face and handle her anxiety during the zombie outbreak to keep surviving.

In this study, the finding of the study was used to be the basis of the discussion. The discussion focused on the protagonist's actions to face her anxiety by adopting Ego Defense Mechanisms. People tend to feel pressure during a survival situation, increasing the anxiety within themselves because they feel cornered and threatened as their life is on edge. They need to do something to reduce their anxiety and survive as survival is their primary need during a survival situation. The analysis of how the protagonist handled her anxiety through Ego Defense Mechanisms can be seen as follows.

\section{Datum 1}

Picture 1 Do Nothing When Being Threatened by a Gun

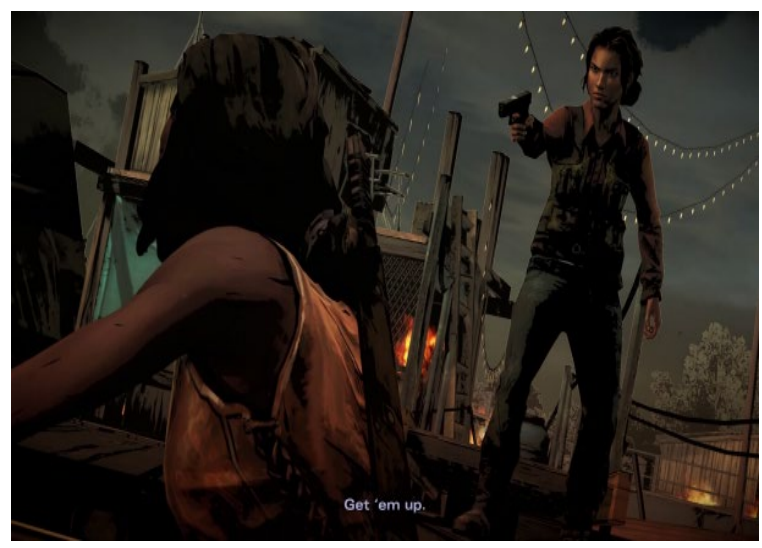

Michonne, the protagonist, tried to escape after burning the enemies' base camp by using the flare gun. She does not intend to burn it at first, but when she shot the flare gun, it exploded and burned down the place in a short amount of time because the basecamp was primarily made of wood. During the escape process, she fought and killed some of 
them because the enemies threatened her, and some of them almost killed her by using a shotgun. Not long after the escape attempt, Michonne stumbled and fell. Unfortunately, when she tried to escape, she was stopped by an enemy who aimed a gun at her. When being threatened with a gun by the enemy, Michonne did not fight back and stayed still. In this scene, she tried to hold back her anger and fear, so the enemy would not shoot her because the enemy would think that she was surrender. Michonne also realized that her friend was right behind the enemy to tackle her down. Therefore, she increased her chance of survival by holding back her anger and anxiety. Repression, one of the Ego Defense Mechanisms, was adopted by Michonne because we can see from the picture above that she did not try to fight back the enemy and wait until her friend saves her. In Minderop (2010), Freud claimed that repression is an unconscious mechanism formed by the ego to keep disturbing or threatening thoughts from entering our unconscious mind.

As seen in the scene, she needs to do something to reduce her anxiety and increase her chance of surviving. Attacking the enemy with bare hands is impossible because the enemy pointed a gun at Michonne. Even though she has her machete with her, it is tough to attack the enemy as the machete can only be used for short-range combat. Therefore, she repressed her uncomfortable feelings by not doing anything while being threatened by the enemy. She realizes that if she fought back or moved a single inch, she would be shot and killed. When the enemy approached her, she realized that one of her friends was right behind the enemy to help her by walking quietly, and she continued to stare as the enemy was getting closer. By staying quiet, she let her friend ambush and take down the enemy, thus saving her life.

From the explanation above, the protagonist's repression was done because she was trying to reduce her anxiety by repressing her uncomfortable feelings when being threatened by the enemy. She stood still because she did not have any options left to escape from the enemy, which was a rational decision to make. In that situation, her friend was also trying to help her. Thus, she did not do anything to distract the enemy. It would give her friend some time to attack the enemy from behind and make them able to escape. Therefore, this was proof of her success in controlling her anxiety by repressing and turning it into a survival tactic to keep her and her friends survive longer.

In previous studies, repression was shown by the characters to repress the uncomfortable feelings and thoughts to make them feel better, reduce their anxiety and achieve their goals. For example, in the study by Martono (2016), the main character, Sasana is transgender. He applied repression to forget his fear, anxiety, bitter memories, and experiences of being discriminated in the past to feel peace within him. Compared to the present study, a significant difference can be noted on why the characters applied repression based on their situation. Sasana from Pasung Jiwa as discussed by Martono (2016) applied repression in order to forget everything in his past life to achieve peace without any interference, while Michonne from The Walking Dead: Michonne applied repression in order to repress her anxiety, fear, and anger to keep her from committing reckless actions that helped her to survive during the zombie outbreak. Therefore, the actions of the two characters above were in line with the theory of Ego Defense Mechanisms by Sigmund Freud, particularly, repression. Although the characters in Pasung Jiwa and The Walking Dead: Michonne applied repression with different reasons and situations, the two characters utilized this mechanism as an internal process within human beings to prevent unpleasant or threatening feelings from entering the unconscious mind. 


\section{Datum 2}

\section{Picture 2 Cutting the Zip Tie}

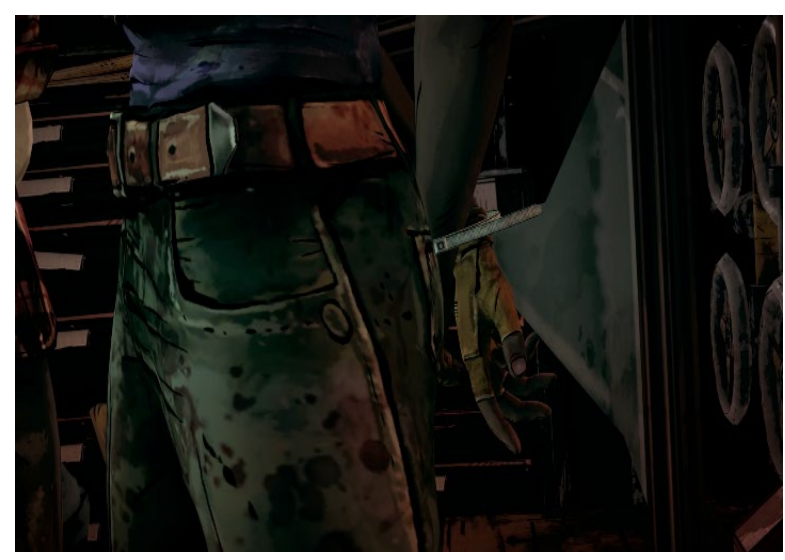

Being held captive, the protagonist had to do something to escape from the community. When one of her friends was accidentally shot by the enemy, she quickly tried to break free from the zip tie. She came across a broken mirror in front of her and tried her best to think clearly about how she could cut the zip tie as fast as possible. She finally cut the zip tie without hesitation to break free and help her friend. Based on the protagonist's action, a part of Ego Defense Mechanisms, namely, sublimation, is shown by the protagonist. She turned her fear and anxiety into constructive action, which uses a piece of a broken mirror to break free from the zip tie so that she can help her friend who is getting shot by the enemy. Freud (in Minderop, 2010) stated sublimation is the act of replacing the feeling of anxiety with socially beneficial acts.

After one of her friends gets shot during this scene, she panicked, and it increased her anxiety. Pressured by her anxiety, she quickly acted and turned her anxiety into constructive action by cutting the zip tie because she believed it was the only way to break free. By doing so, she could cut the zip tie and immediately helped her friend. This showed that sublimation helped Michonne and influenced her to think quickly, and turned her fear into a constructive or beneficial act when she felt pressured by her anxiety.

The explanation above showed that the anxiety and fear that she felt became a strong will for her to survive and escape from the place that she was being held. Therefore, it could be concluded that the protagonist successfully handled her anxiety and turned it into her power and constructive action. Sublimation was proven to be applied when she finally managed to break free from the zip tie immediately by using a piece of the broken mirror because of her fear and anxiety.

Sublimation was also shown in the previous study by Santoso (2017), who discussed Lu Xun's short story. Kong Yiji was the main character in the second short story by Lu Xun. Facing countless times of failures in a test to become an employee in the government offices, he became hopeless and powerless. These feelings increased his anxiety. He thought that he had lost in life and gave up hope. However, slowly but surely, instead of remaining sad and hopeless, he turned his sadness into a constructive action, that was to continue writing. In fact, Kon Yiji was a talented writer with beautiful handwriting. He managed to use his gifted ability in a positive way to change his hopelessness. As time went by, everyone loved his writings.

Comparing the application of sublimation by Kong Yiji in Santoso (2017) and Michonne in this study, the same purpose of utilizing sublimation as a defense mechanism was obviously shown. Both Kong Yiji and Michonne turned their anxiety, fear, sadness, and hopelessness into constructive actions. Kong Yiji turned his negative feelings into the action of creating beautiful handwriting, while Michonne turned her negative feelings into the action of breaking herself free when she was held captive. Michonne used the broken mirror to cut the zip-tie. The comparison of the characters' actions shed some light on the successful acts of the characters when choosing sublimation, one of the Ego Defense Mechanisms. Despite the different situations to be faced, it was clear that the characters applied sublimation with the same intention. Both of them replaced the feeling of fear or anxiety with socially beneficial activities as the reflection of sublimation. 


\section{Datum 3}

\section{Picture 3 Stating That They Don't Have a Choice}

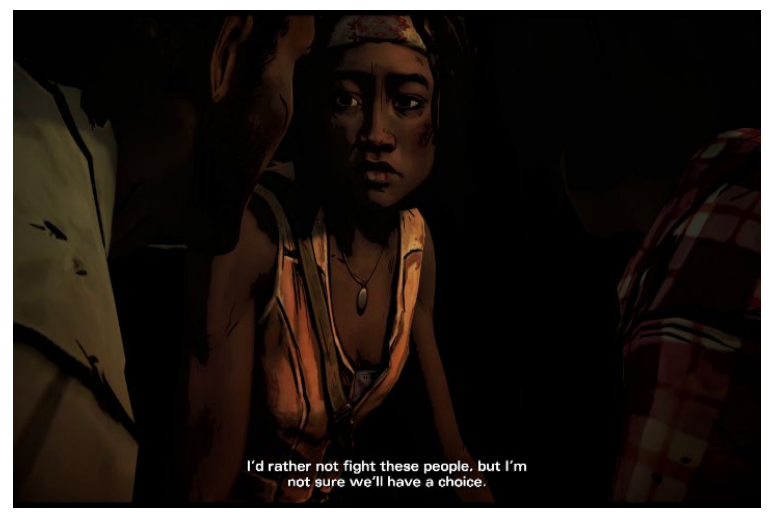

After breaking free from the underground where Michonne and her friends were held captive, they hid inside a boat and tried to figure something out to escape from the island. During that situation, everyone was scared if they could not make it out alive. Sam, one of Michonne's friends, suggested that they should just make an offensive attack to escape from the community to keep surviving. Pete disagreed with the idea at first, and then Michonne replied by saying, "I'd rather not fight these people, but I'm not sure we'll have a choice." which indicated that she was scared too, but in order to survive and escape, they had to fight back because they had no other choices or options on how they could escape. By the time, the enemies had been looking around for Michonne and her friends.

Moreover, one of Michonne's friends had been killed. Michonne thought it would be fair if they attacked the enemy directly because if they surrendered, their chance of getting killed was high. Those considerations made her decision that the enemies could not be trusted any further because of their actions.

Her statement from the previous paragraph showed rationalization as one of the Ego Defense Mechanisms proposed by Freud. Rationalization is to give a person acceptable motives for their behavior, attitude, or actions (Minderop, 2010). Michonne's statement implied that she did not want to fight the enemy because she knew that by fighting them, she also had to kill them when they attacked her first, but she also had no choice. After all, if she and her friends did not escape and attack the enemy directly, they would be killed. It was the only rational decision to make in that situation. It was because Michonne and her friends were outnumbered.

When she felt that she was cornered in that life-threatening situation, she turned her fear and anxiety into an act of making a rational decision. Then she fought the enemy directly and escaped together. She did it not because she liked or enjoyed torturing them, but because the enemy killed her friend and they were going to kill Michonne and her friends if she did not do something to escape. Therefore, based on her actions and motives for fighting back the enemies, it was proven that she controlled her anxiety very well and made a rational decision even though she was not quite sure about the outcomes. Seen from both points of view, Michonne's decision, motives, and actions to fight back the enemies were acceptable.

In line with this finding, rationalization was also found in one of the short stories by Lu Xun (Santoso, 2017). The unnamed main character felt anxious when he realized that the wild animals he hunted were gone and he decided to eat a wild boar instead. He realized that a wild boar was not hygienic and might cause serious diseases. However, as he was feeling extremely hungry and there was nothing left to eat, he had no choice. The characters from Lu Xun's short story and The Walking Dead: Michonne applied rationalization to show their reasonable motives behind their actions. The unnamed main character realized that it was wrong to consume wild boar because it might cause a disease. Since he had nothing left to eat, it made his action acceptable in order to keep surviving, while in the present study, Michonne realized that she was scared but had no other choice but to fight the enemies directly in order to stay alive. Therefore, rationalization was shown by both characters with the same purpose, which was to survive. The characteristic of rationalization as one of the Ego Defense Mechanisms was strongly applied when the characters in the story had reasonable motives for their actions. 


\section{Datum 4}

\section{Picture 4 Smashed Randall's Face to the Table}

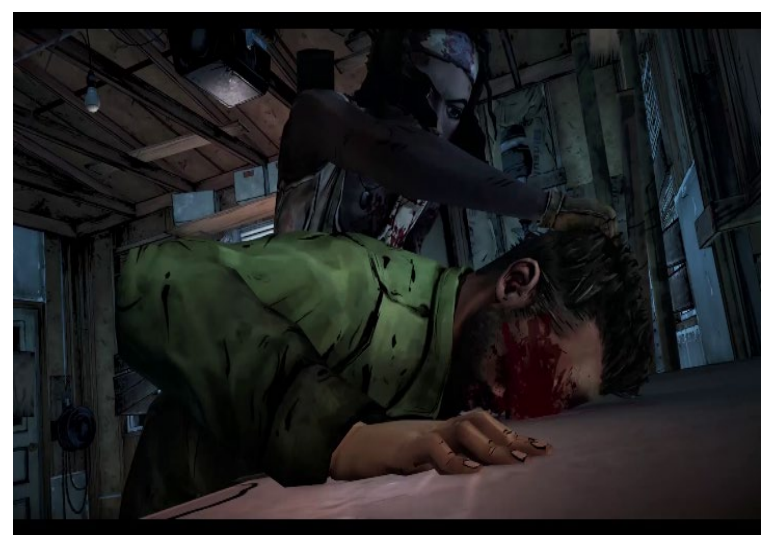

During one of the scenes, the protagonist was involved in hand-in-hand combat with the enemy's leader, Randall. She tried to fight him back to protect everyone from Randall's harm, but he was too strong for Michonne to be fought alone. He punched Michonne several times until one of Michonne's friends hit Randall's head with a shovel. Randall then fell to the ground while holding his head because of the pain caused by the sudden attack. When Michonne regained her consciousness, she became furious at Randall for what he did. Michonne was highly frustrated and upset with Randall. Michonne then finally got her chance and attacked Randall, smashed his face to the table several times to weaken him to be tied so that she could use him as a bargaining chip to release her friends, whom Randall's minions captured.

The will and action of fighting back and smashing Randall's face were influenced by one of the Ego Defense Mechanisms known as aggression. Overwhelmed by how influential Randall was, she was afraid if she did not hit him as hard as she can, he would be able to take her down and kill everyone there, including herself, because Randall is physically strong Michonne and her friends.

The adrenaline and anxiety within Michonne arose, and she released it by smashing Randall's head several times to the table to weaken Randall, so he could not fight back. Freud claimed that an act of releasing anger or disappointment that is directly shown to another object or to someone that causes anxiety or frustration is known as Aggression (Minderop, 2010). She was feeling anxious, yet, she was also determined to fight Randall to protect her companion.

Specifically, this study found aggression was applied by the main character. This mechanism was not chosen by the characters discussed in the previous studies. This finding became the uniqueness of The Walking Dead: Michonne in terms of how the characters in the story used the Ego Defense Mechanisms. From the scene and explanation of aggression found in this study, the main character, Michonne turned her fear, anger, and anxiety towards Randall's violent actions into a strong will and power to fight him back. She chose aggression to protect all people around her. She was afraid that Randall would kill them because he was a cold-blooded man. Michonne thought that she had to save people's life. Moreover, Randall's aggressiveness led Michonne to do an aggressive action. In such a situation, she applied aggression to calm her anger. At the same time, she also reduced her anxiety. It was also proof that she successfully controlled her anxiety and turned it into a will and power to fight back and survive. Her action demonstrated the application of aggression because she was extremely furious at Randall for his evil deeds. She ended up maliciously hurting him because her anger towards Randall was unbearable. As obviously explained by Sigmund Freud supported by the example of Minderop (2010), Michonne's actions reflect the act of releasing resentment or dissatisfaction. The aggressive actions were shown specifically to the ones that created anxiety or frustration. In the case of The Walking Dead: Michonne, the main character wanted to release her dissatisfaction from Randall's evil deeds.

\section{Conclusion}

This study focused on analyzing how the protagonist from The Walking Dead: Michonne movie game coped with her anxiety through Ego Defense Mechanisms based on Sigmund Freud's theory. Based on the study results, four types of Ego Defense Mechanisms 
were found to be adopted, namely repression, sublimation, rationalization, and aggression. The protagonist utilized them to handle her anxiety. By analyzing the protagonist's actions and dialogue, aggression was the most frequently adopted mechanism, i.e., 12 times (32\%), sublimation took place ten times $(27 \%)$, rationalization happened eight times $(22 \%)$, and repression occurred seven times (19\%).

Ego Defense Mechanisms influenced the protagonist's actions to reduce or face her anxiety throughout the story. The protagonist character chose aggression that was explicitly shown to another object or someone that created anxiety or frustration to release the resentment or dissatisfaction. Besides, she controlled her anxiety successfully by applying the other three Ego Defense Mechanisms like sublimation, rationalization, and repression. The application of the four mechanisms turned her anxiety into some actions that helped her survive during the zombie outbreak.

The present study is in no way conclusive on its own. Further studies on The Walking Dead: Michonne as well as on other movie games, along with the ego defense mechanism adopted by their main characters. Such analyses will provide more generalizations of what ego defense mechanism mostly adopted. Studies on ego defense mechanisms should also be extensively researched among students and in society to enrich the kinds of literature on ego defense mechanisms as part of the efforts to create a better psychological mechanism for society.

\section{References}

Al Khoiriyah, D. S. (2019). Unconscious Mind and Anxiety in the Main Character of Face in the Crowd Movie Script by Julian Magnad. Linguistic, English Education and Art (LEEA) Journal, 3(1), 238-246. https://doi.org/10.31539/leea.v3i1.984
Chandiwati, A. G., Karnadi, H., Renaningtyas, L., Studi, P., Komunikasi, D., Seni, F., ... Surabaya, P. (2016). Perancangan Komunikasi Visual "Bermain Video Game Itu Sehat dan Kreatif" Sebagai Kampanye Game Pump It Up Untuk Remaja. DKV Adiwarna, 1(8), 9.

Hall, C. S. (2019). Psikologi Freud: Sebuah Bacaan Awal. (T. Setiadi, Ed.). Yogyakarta: IRCiSoD.

Hasan. (2019). Makalah Ilmu Sosial Budaya Dasar Pengaruh Game Online Terhadap Anak-Anak Dan Remaja Disusun Oleh: Hasan Management Dual Degree. Padang.

Henman, S. (2019). Choosing Your Own Adventure: The History of Interactive Movies.

Hossain, M. M. (2017). Psychoanalytic theory used in English literature: A descriptive study. Global Journal of Human-Social Science: Linguistics \& Education, 17(1), 4146.

Khoirunisa, N., \& Rahayu, Y. E. (2020). Ego Defense Mechanisms of the Main Female Characters in Maleficent Movie. Dinamika Bahasa Dan Budaya, 15(2), 54-61.

Manggena, T. F., Putra, K. P., \& Elingsetyo Sanubari, T. P. (2017). Pengaruh Intensitas Bermain Game Terhadap Tingkat Kognitif (Kecerdasan Logika-Matematika) Usia 8-9 Tahun. Satya Widya, 33(2), 146-153. https://doi.org/10.24246/j.sw.2017.v33.i 2.p146-153

Martono, N., Rosa, H. T., \& Azmin, G. G. (2015). Mekanisme Pertahanan Ego Pada Tokoh Transgender Dalam Novel Pasung Jiwa Karya Okky Madasari: Suatu Kajian Psikologi Sastra. Arkhais - Jurnal Ilmu Bahasa Dan Sastra Indonesia, 7(2), 87-92. https://doi.org/10.21009/arkhais.072.05

Minderop, A. (2010). Psikologi Sastra: Karya Sastra, Metode, Teori, dan Contoh Kasus. Jakarta: Yayasan Pustaka Obor Indonesia.

Musoffa, D., Multazim, A., Husna, A., Hudayah, L. F., \& Dramestika, R. (2019). Man Anxiety as Reflected in Ernest Hemingway's The Old Man and the Sea. Journal of Language and Literature, 19(2), 20. https://doi.org/10.24071/joll.v19i2.2117

Novrialdy, E. (2019). Kecanduan Game Online pada Remaja: Dampak dan Pencegahannya. Buletin Psikologi, 27(2), 148. https://doi.org/10.22146/buletinpsikologi .47402 
Nurtjahyo, G. (2016). The Anna Leonowens' Anxieties and Ego Defense Mechanisms As Found in Elizabeth Hand'S Anna and the King: a Freudian Psychoanalytical Approach. EduLite: Journal of English Education, Literature and Culture, 1(1), 17. https://doi.org/10.30659/e.1.1.17-27

Pangestu, N. A., \& Sunardi, F. X. D. (2016). an Incomplete Psychological Novel: a Psychoanalytical Analysis of Hazel Lancaster in John Green'S the Fault in Our Stars. Journal of Language and Literature, 16(01), 20-28. https://doi.org/10.24071/joll.2016.16010 3

Pratama, B. N., \& Aji, G. F. S. (2017). Willy Wonka'S Narcissistic Personality in Roald Dahl'S Charlie and the Chocolate Factory. Journal of Language and Literature, 17(1), 36-48.

https://doi.org/10.24071/joll.2017.17010 5

Purwaningrum, L., \& Haryati S., N. (2016). Pengaruh Pola Asuh Permisif Terhadap Perkembangan Kepribadian Tokoh Utama Novel Mendung Tak Bermalam Karya Abu Umar Basyier: Kajian Psikologi Sastra. Lingua, 11(1), 13-24.

Rexroth, K. (2019). literature | Definition, Scope, Types, \& Facts | Britannica. In Britannica.

Santoso, D. D. (2017). Kecemasan dan Mekanisme Pertahanan Ego Tokoh Utama Dalam Kumpulan Cerpen (Lǔ Xùn Xiăoshuō Quánjí 鲁迅小说全集) Karya Lu Xun (Kajian Psikoanalisis Sigmund Freud). Paramasastra, 4(2), 287-307. https://doi.org/10.26740/parama.v4i2.15 33

Semiun, Y. (2006). Teori Kepribadian dan Terapi Psikoanalitik Freud. Yogyakarta: Penerbit Kanisius.

Setiawan, H. S. (2018). Analisis Dampak Pengaruh Game Mobile Terhadap Aktifitas Pergaulan Siswa Sdn Tanjung Barat 07 Jakarta. Faktor Exacta, 11(2), 146. https://doi.org/10.30998/faktorexacta.v1 $1 \mathrm{i} 2.2338$

Suwastini, N. K. A., Widasuari, N. W. D., Wahyuni, L. G. E., \& Visestayati, N. P. A. (2020). Lucy Pevensie'S Characterizations in C.S. Lewis's Narnia: the Lion, the Witch, and the Wardrobe. International Journal of Language and Literature, 4(1), 47. https://doi.org/10.23887/ijll.v4i1.30227

Suwastini, N. K. A., Dantes, G. R., Jayanta, I. N. L., \& Suprihatin, C. T. (2020). Developing Storyline for Role-Playing Games Based on Balinese Folklore for Preserving Local Wisdom and Character Education. 394(Icirad 2019), 361-366. https://doi.org/10.2991/assehr.k.200115. 059

Syahran, R. (2019). Anxiety and Defense Mechanism of Jordan Garrison In Eric $V$. Copage' $S$ Between Father And Son. Universitas Islam Negeri Maulana Malik Ibrahim Malang.

Ulfa, N., \& Wulandari, D. F. (2019). Analysis of Anxiety and Defense Mechanism on the Main Character Reflected in Alice ' $s$ Adventures in Wonderland ( 1865 ) Novel by Lewis Caroll. Konferensi Ilmiah Mahasiswa Unissula (KIMU), 739-745.

Warkey, E., Sili, S., \& Asanti, C. (2020). Moses ' Anxiety and Defense Mechanisms in Exodus: Gods and Kings Movie. Ilmu Budaya: Jurnal Bahasa, Sastra, Seni, Dan Budaya, 4(1), 93-107. 